\title{
Dördüncü Sanayi Devrimi Çerçevesinde Koşulsuz Temel Gelir: Türkiye İçin Bir Değerlendirme ${ }^{1}$
}

\author{
M. Mustafa Erdoğdu² \\ Sevda Akar ${ }^{3}$
}

Dördüncü Sanayi Devrimi Çerçevesinde Koşulsuz Temel Gelir: Türkiye İçin Bir Değerlendirme

Öz

Bu makalenin temel amacı, yoksulluğu ve gelir eşitsizliğini azaltabilecek kısmi bir çözüm olarak kabul edilen koşulsuz temel gelire (KTG) ilişkin tartışmaları değerlendirmektir. Çalışma ilk olarak gelir eşitsizliği ile neoliberalizmin hâkim iktisat anlayış haline gelmesi arasında bir ilişki olup olmadığı sorusuna cevap aramaktadır. İkinci olarak Türkiye gibi bazı ülkelerde önemli ölçülerde artan işsizlik oranları ile derinleşen 4. Sanayi Devrimi (4. SD) arasında bir ilişki olup olmadığını sorgulamaktadır. Üçüncü olarak kapitalist bir ekonomik sistemde hiç kimseyi aç ve korunmasız bırakmayacak politikaların uygulanıp uygulanamayacağı sorusuna cevap aramaktadır. Dördüncü olarak yukarıdaki sorulara tatminkâr cevaplar bulabilmek için makale, Brezilya, Hindistan, $A B D$, Kanada ve Finlandiya'dan bazı temel gelir deneylerini kısaca değerlendirmektedir. Daha sonra Türkiye'de üç alternatif KTG uygulamasının bütçe üzerinde oluşturacağı maliyetler hesaplanmaktadır. Son olarak, topluma olumlu dışsallık yayılma olasılığını arttırmak için makale mütevazı bir teorik katkıda bulunmaktadır.

Anahtar Kelimeler: Koşulsuz Temel Gelir, Yoksulluk, Dördüncü Sanayi Devrimi, Olumlu Dışsalıklar, Türkiye
Unconditional Basic Income in the Framework of the Fourth Industrial Revolution: An Assessment for Turkey

Abstract

The main purpose of this article is to evaluate the arguments about the unconditional basic income (UBI), which is considered as a partial solution to alleviate poverty and reduce income inequalities. The study will first explore if there is a relationship between income inequality and neoliberalism, which is the dominant economic understanding. Second, it will examine if there is a relationship between an increase in unemployment rates in some countries like Turkey and the deepening of the 4th Industrial Revolution (4th IR). Third, it will seek an answer if it is possible to implement policies that will not leave anyone hungry and vulnerable in a capitalist economic system. Fourth, the paper will briefly evaluate some basic income experiments from Brazil, India, the US, Canada, and Finland to find satisfactory answers to the above questions. Next, the budgetary costs of three alternative UBI possibilities for Turkey are calculated. Finally, the article will make a modest theoretical contribution to increasing the likelihood of positive externality spread to society.

Keywords: Unconditional Basic Income, Poverty, Fourth Industrial Revolution, Positive Externalities, Turkey

\section{Giriş}

Sanayi devrimi ya da diğer adıyla endüstri devrimi, 18. yüzyıldan 21. yüzyıla kadar teknolojik gelişmenin somut bir göstergesi olarak sürekli gündemde olmuştur. Günümüzde dördüncüsü yaşanmakta olan son sanayi devrimi ile birlikte giderek artan sayıda işletme, üretimde otomasyon ve robot kullanımını üst seviyelere çıkartmış, üç boyutlu (3D) yazıcı, nesnelerin interneti (IOT), yapay zekâ (AI) gibi yenilikleri üretim sürecine dâhil etmeye başlamıştır. Dijital devrim üzerinde yükselmekte olan 4. sanayi devrimini (4. SD) önceki devrimlerden farklı kılan, Schwab (2016: 17)'ın da işaret ettiği gibi, teknolojilerin iç içe geçip kaynaşarak fiziksel, biyolojik ve dijital alanlarda karşııkı etkileşimde bulunmalarıdır. Bu yenilikler sermaye birikimini,

\footnotetext{
1 7. International Congress on Current Debates in Social Science (CUDES 2018) Sempozyumunda özet olarak sunulan tebliğin geliştirilmiş halidir.

2 Prof. Dr., Marmara Üniversitesi, İktisat Fakültesi, Maliye Bölümü. mustafaerdogdu@marmara.edu.tr, Yazar ORCID bilgisi: orcid.org/0000-0003-4541-6686

${ }^{3}$ Doç. Dr., Bandırma Onyedi Eylül Üniversitesi, IiBF, Maliye Bölümü, sevdamutluakar@gmail.com, Yazar ORCID bilgisi: orcid.org/0000-0003-1208-0258
} 
verimliliği ve büyümeyi olumlu yönde etkilemektedir. Ancak 4.SD, işsizlik gibi toplumsal yaşa$\mathrm{m}$ derinden etkileme potansiyeline sahip tehditleri de içinde barındırmaktadır.

Eğilmez (2017)'e göre, 4. SD’nin üç temel etkisi bulunmaktadır. Bunlardan birincisi, emek ihtiyacını en aza indirerek üretimde meydana gelen insan kaynaklı hataları azaltmak; ikincisi, üretimde esneklik sağlayarak tüketiciye özel ürünler yapabilmek; üçüncüsü ise, üretimi hızlandırmaktır. Aydın ve Demiral (2019) da Schwab (2016) ve Eğilmez (2017) gibi, 4. SD’nin diğer devrimlerden çok daha hızı bir şekilde üretimi dönüştürdüğüne ve küresel toplumu derinden etkilediğine vurgu yapmaktadır. 4.SD ile başlayan bu değişim ile birlikte birçok işin yeniden tanımlanacağı, bazılarının yok olacağı, daha önce var olmayan bazı yepyeni mesleklerin ise sıfırdan ortaya çıkacağı konusunda genel bir uzlaşma bulunmaktadır.

Kapitalizm insanın yaşamını idame ettirebilmesini emeğini satmasına bağlamıştır. Ancak 16. yüzyıldan itibaren özellikle hümanist düşünürler bu anlayışın karşısına, sosyal güvencenin bireyin çalışma performansı ile değil, toplumun bir üyesi olmayla ilişkilendirilmesi gerektiği görüşünü ortaya koymuşlardır. Bu önerinin özünü Buğra ve Keyder (2007) bireylere, sadece toplumun bir ferdi olmaları sebebiyle koşulsuz ve düzenli bir nakit gelir sağlanması olarak tanımlamaktadırlar.

Temel gelir önerisi ilk olarak 1797 yılında Thomas Paine tarafından gündeme getirilmiştir. Teknolojik gelişmelerin istihdam üzerindeki olumsuz etkisinin bir sonucu olarak artan güvensizlik, günümüzde koşulsuz temel gelir fikrini yeniden canlandırmıştır. Temel gelir, otomasyonun ve robotların yol açtığı yapısal işsizlik nedeniyle artık sadece sosyal ve ahlaki bir yükümlülük değil, aynı zamanda mevcut ekonomik sistemin sürdürülebilirliği açısından da bir zorunluluk haline gelmiştir. Illginç bir şekilde son yıllarda koşulsuz temel gelir 4.SD’ne yön veren ve onun kazananları arasında yer alan Elon Musk ve Mark Zuckerberg gibi teknoloji şirketlerinin CEO'ları tarafından 4.SD'nin olumsuz etkilerine karşı bir önlem olarak gündeme taşınmaya başlamıştır.

Son yıllarda dört farklı kıtada, aralarında hem çok güçlü hem de çok zayıf refah sistemlerine sahip ülkelerin bulunduğu birçok ülkede temel gelir deneyleri uygulama konulmuştur. Prochazka (2019, 4 Haziran)'nın ifade ettiği gibi, bu deneyler koşulsuz temel gelirin insanları daha mutlu, daha sağlıklı ve gerçekten ilgi duydukları faaliyetleri gerçekleştirebilmek için daha özgür kıldığını göstermektedir. Gerçekleştirilen deneyler, özellikle temel gelirin çoğu kimsenin öngördüğü gibi çalışma isteğini azaltmadığını ortaya koymuştur. Bu önemli bulgu, koşulsuz gelire yönelik kamuoyu ilgisini artırıcı bir işlev görmektedir.

Bu çalışmanın temel amacı, son yıllarda yoğun bir şekilde tartışılmakta olan koşulsuz temel gelire yönelik argümanları ve bugüne kadarki başlıca uygulama sonuçlarını değerlendirmektir. Çalışma şu şekilde organize edilmiştir. Takip eden kısımda koşulsuz temel gelir fikrinin kısaca nasıl ortaya çıktığı, bugüne kadar ne gibi tartışmalara konu olduğu, neo-liberal küreselleşmenin gelir dağılımını bozucu etkileri ve 4.SD’nin yol açtığı yapısal işsizlik sorunu ele alınmıştır. Üçüncü bölümde dünyada şartlı nakit transferi, koşulsuz temel gelir ve benzeri uygulamalara ilişkin ABD, Kanada, Brezilya, Hindistan ve Finlandiya gibi bazı ülkelerde yapılan deney ve uygulamalar incelenmiştir. Dördüncü bölümde Türkiye'de mevcut ekonomik kriz koşullarında bir temel gelir uygulanmasının ne gibi olası sonuçlar doğurabileceği sorusuna cevap aranmıştır. Sonuç kısmında çalışmanın temel bulguları değerlendirilmiştir. 


\section{Zamanı Gelmiş Bir İdeal Olarak Koşulsuz Temel Gelir}

Koşulsuz temel gelir (KTG) ya da başka bir ifadeyle evrensel temel gelir tüm vatandaşlara sürekli ve koşulsuz olarak sağlanan bir geliri ifade etmektedir. Koşulsuz temel gelir, vatandaşın geliri, asgari garantili gelir, temel gelir garantisi veya daha basit bir ifadeyle temel gelir olarak adlandırılmaktadır. BIEN (2018: 1)'e göre, temel gelir, herkese koşulsuz ve tamamen bireysel olarak verilen düzenli bir nakit ödemedir.

Temel gelir fikri, tüm bireylerin yoksulluk sınırının üzerinde yaşamasını garanti eden bir yeniden dağıtımı önermektedir. KTG'e ilişkin ilk çalışmalar mevcut refah programlarının arzulanan sonuçları vermekten uzak olması nedeniyle başlamıştır. Günümüzdeki çalışmaların çıkış noktasını daha çok 4.SD teknolojilerindeki gelişmelerin işsizliği giderek artıracağı beklentisi oluşturmaktadır. Belirtmek gerekir ki, KTG uygulanması sadece insani ve ahlâkî değil, aynı zamanda toplumsal uyumun sürdürülebilirliği açısından da bir gerekliliktir.

Laurinavičius ve Laurinavičius (2016)'ın işaret ettikleri üzere temel gelir, ilk olarak 18. yüzyılın sonlarına doğru Thomas Paine'in Tarım Adaleti çalışması ile formüle edilmiş ve 20. yüzyılın sonunda bu fikir P. Van Parijs (2004) tarafından geliştirilmiştir. Temel gelir fikri, tüm bireylerin yoksulluk sınırının üzerinde yaşama fırsatını garanti eden bir yeniden dağıtımı önermektedir. Parijs (2004)'in standart tanımı, çalışma veya başka bir şart söz konusu olmaksızın bireylere bir gelir ödenmesidir. Dolayısıyla evrensel niteliktedir. Finansal durumları değişse bile bireylere aynı ödeme yapılmaya devam edilebilir ve herhangi bir davranışsal gerekliğe tabi değildir.

KTG herhangi bir geçici işsizlik ödeneği veya yardım sistemi ile karıştırılmamalıdır. KTG herhangi bir hibe, sübvansiyon veya şartlı işsizlik ödeneği değildir. KTG'i almanın tek şartı vatandaşlık veya akredite ikametgâhtır. KTG emek piyasasına değil sosyal haklara dayalı çözümlere vurgu yapan, konuyu teknokratik değil, ahlâkî-politik olarak ortaya koyan bir açılımdır. Lucarelli ve Fumagalli (2008) KTG'i, sermaye ve emek arasında daha adil bir uzlaşma ve daha sağlıklı bir toplumsal düzen sağlayan vazgeçilmez bir yapısal ekonomik politika olarak tanımlamaktadır.

Temel gelir her derde deva bir uygulama değildir. Ancak sosyal politikaların üzerine oturtulabileceği bir temel, bir sosyal taban sağlayabilir. Temel gelir programının sosyal eşitlikçi (egalitarian) düşünce ile negatif gelir vergisi programının adil dağılımını esas alan özgürlükçü (libertarian) düşünceyle uyumlu olduğu görülmüştür. Koşulsuz temel gelir, teorik olarak evrensel ve koşulsuz bir götürü transfer uygulamasıdır. Basit doğrusal bir vergi sisteminde, negatif gelir vergisinde fayda denklem (1)'e göre belirlenmektedir (Tondani, 2009: 247):

$$
\begin{array}{lr}
B=G-t^{\wedge} \alpha Y & 0 \leq Y \leq \delta \\
B=t^{\wedge} \alpha(\delta-U) & Y \geq \delta
\end{array}
$$

Denklemde yer alan $B^{\prime}$ nin net fayda (negatif işaret ile) veya ödenen vergi (pozitif işaret ile); $Y$ brüt gelir; G, sıfır gelirli bireylere ödenen azami negatif gelir vergisi miktarı; $\delta$ kesinti miktarı ve $t^{\wedge} \alpha$ vergi oranıdır. Evrensel temel gelirde ise fayda 3 numaralı denkleme göre hesaplanmaktadır.

$B=g-t^{\wedge} \sigma Y$

$Y^{\prime}$ nin herhangi bir değeri için, $\mathrm{t}^{\wedge}(\sigma)$ vergi oranı; g, faydanın (azaltma) sabit ve evrensel bir seviyesidir. Yeniden dağıtım sonrası harcanabilir gelirleri gözlemleyerek, iki planın da yeniden dağıtım sonuçları açısından benzer olabileceğini görmek mümkündür. Evrensel temel gelir için 
harcanabilir veya vergi sonrası gelir, $\mathrm{Y}_{-} \mathrm{d} 4$ numaralı denklemde negatif gelir vergisi için harcanabilir gelir ise 5 numaralı denklemde gösterilmektedir.

$$
\begin{aligned}
& Y_{-} d=Y+B=g+\left(1-t^{\wedge} \sigma\right) Y \\
& Y_{-} d=Y+B=\left(1-t^{\wedge} \alpha\right) Y+t^{\wedge} \alpha \delta
\end{aligned}
$$

$\mathrm{Bu}$ denklik ile, herhangi bir düzeyde brüt gelir, aynı marjinal ve ortalama vergilendirme profili için aynı harcanabilir geliri veren KTG ve negatif gelir vergisi şemalarını tasarlamak mümkündür (Tondani, 2009: 247). Temel gelir ile negatif gelir vergisi teklifleri arasındaki ilişki Şekil 1'de yer almaktadır. Hem temel gelir hem de negatif gelir vergisi grafiklerinde dikey eksen, vergi sonrası geliri, yatay eksen ise vergi öncesi geliri göstermektedir. Ancak, belirli bir garanti seviyesinde vergilerin kabul edilmesi, negatif gelir vergisi planı ile aynı sonuçlara ulaşmaktadır. Temel gelir planı olarak, aynı brüt transferi ve vergi tabanındaki diğer kaynaklardan elde edilen tüm gelirler yerine, sadece bazı kişilere net transfer yaparak ve diğerlerinden borçlu oldukları net vergiler düşürülerek oluşturulabilir (Parijs, 1992: 484).

\section{Şekil 1: Negatif Gelir Vergisi ve Koşulsuz Temel Gelir}

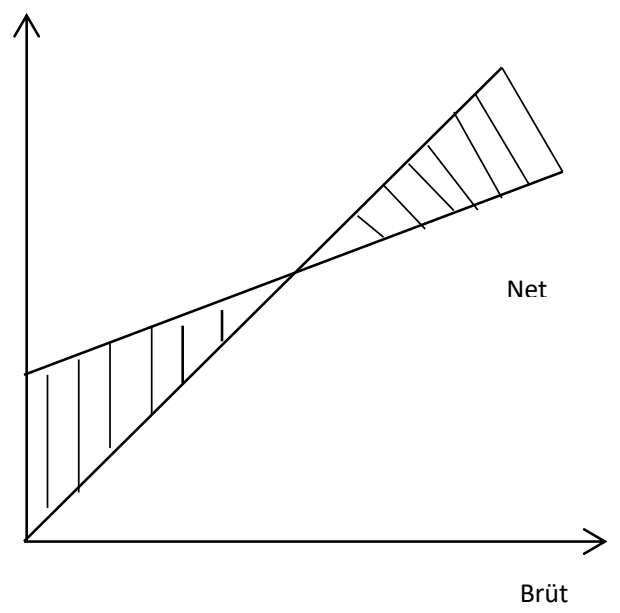

Negatif Gelir Vergisi

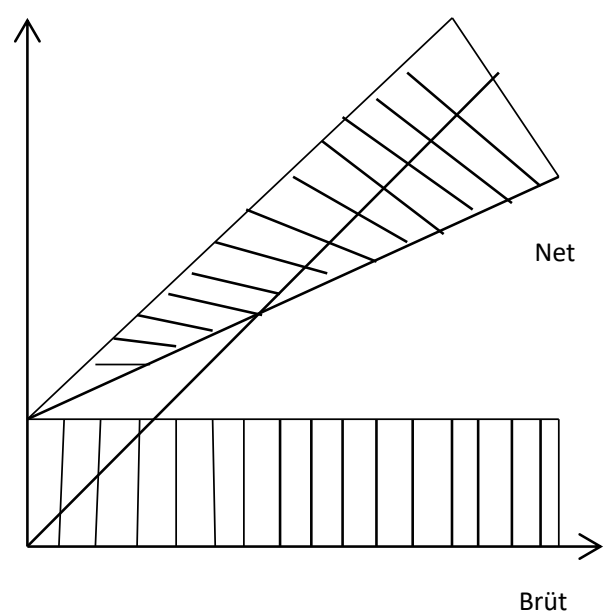

Koşulsuz Temel Gelir

Kaynak: Parijs, V. P. (1992), "Basic Income Capitalism", Ethics, Vol. 102, No. 3, 484.

Temel gelir planı, yalnızca bir geliri (gelir vergisi) ve bir koşulu (bireysellik) esas almaktadır. Bu nedenle, temel gelir ile negatif gelir vergisi arasında eşdeğerlik vardır. Ancak temel gelir, tüm şarta bağlı faydaları ortadan kaldıracak yüzeysel açıdan farklı bir plandır ve refahı tek bir mekanizma ile önermektedir - vergi amacı için bireysel ya da hane halkı gelirini hesaplamaktadır. Negatif gelir vergisi, gelir vergisi eşiğinin altında gelirleri olan bireylerin (hane halklarının) vergi ödemek yerine gelir alması gereken bir şemayı ifade etmektedir. Bu durumda olan vatandaşlar olumsuz yükümlülüğe sahip olsalar dahi vergi yükümlüsü sayılmaktadır.

Hernandez (2005)'e göre, KTG yoksulluk sorunlarını ortadan kaldıran, daha eşitlikçi ve adil bir toplum arayışını benimseyen anlayış ile vatandaşların istedikleri gibi yaşamalarını gerçek- 
leştiren özgürlük anlayışını buluşturmaktadır. KTG cinsiyet eşitliği üzerine oturmaktadır. Bir taraftan, daha iyi iş-yaşam dengesi kurmaya olanak sağlama, diğer taraftan işsizlik sonucu ortaya çıkacak geçim sorunlarını ve istikrarsızlıkları ortadan kaldırabilme potansiyeline sahiptir.

\subsection{Koşulsuz Temel Gelir Fikrinin Erken Dönemi}

Temel gelir fikri yazılı kaynaklarda ilk olarak Thomas More'un 1516 yılında kaleme aldığı "Utopia" isimli kitapta yoksulların hayatta kalmak amacıyla suç işlemekten vazgeçmeleri için bir ödeme yapılmasını önermesine kadar geriye gitmektedir. Daha önce ifade edildiği gibi temel gelir önerisi ilk olarak 1797 yılında Thomas Paine tarafından gündeme getirilmiştir. Paine (1797)'in Tarım Adaleti çalışmasındaki önerisi, toprak sahiplerinin topluma karşı bir yükümlülüğü olduğu değerlendirmesine dayanmaktadır. Ona göre, toprak prensip olarak herkese aittir. Ancak tarımsal üretimin sorunsuz gerçekleştirilebilmesi için de mülkiyete konu olması gerekmektedir. O halde, aslında herkese ait olması gereken toprağın mülkiyetine sahip olmaları nedeniyle toprak sahipleri, toprağın sağladığı üretim olanaklarından mahrum kalan kesimlere karşı sorumluluk taşımanın bir gereği olarak 21 yaşına ulaşan gençlere bir kez, 50 yaşın üzerindekilere ise düzenli bir gelir ödemekle yükümlü olmalıdır.

Günümüzde otomasyon ve robot kullanımındaki artış nedeniyle benzer bir durum söz konusudur. Literatürde 4.SD nedeniyle ekonomilerde otomasyona ve teknolojik yeniliklere adapte olamayan işlerin yok olacağı, bu işlerde istihdam edilen bireylerin de işsiz kalacağı görüşü yaygındır. Otomasyonun ve teknolojik yeniliklerin özellikle nitelikli bazı çalışanlara yeni iş fırsatları sağlayacağı aşikâr olmakla birlikte, söz konusu fırsatların daha önceki sanayi devrimlerinde olduğu düzeye ulaşamama, dolayısıyla yapısal işsizliğe yol açma olasılığı yüksektir. Bu durumda yaşanabilecek yoğun işsizliğin yol açacağı sosyal sorunların nasıl aşılabileceği, en çok cevap aranan sorulardan birisi haline gelmiş ve bu çerçevede herkese belli bir geçim düzeyini garanti edecek bir güvenlik ağı oluşturmak anlamına gelen KTG yoğun bir şekilde tartışılmaya başlanmıştır.

Literatürde KTG'yi savunanlar, kişisel özgürlüklerin ve ekonomik verimliliğin artacağını, yoksulluğun azalacağını öne sürerken, KTG fikrine olumsuz yaklaşanlar ise, resmi işgücü piyasasında çalışma teşviklerini önemli ölçüde azaltacağını, dayanışmayı teşvik etmek yerine çeşitli toplum kesimleri arasında sosyal dışlamayı arttıracağını ve derinleştireceğini iddia etmektedirler. Bowman vd. (2017)'e göre, yoksulluğun hafifletilmesi, ekonomik güvenliğin sağlanması ve teknolojik değişime cevap verebilmek açısından temel gelir düşüncesi çekici olmakla birlikte, istenmeyen sonuçlar da doğurabilir. Bu nedenle önerilecek herhangi bir teklifin detaylarının dikkatli bir şekilde değerlendirilmesi gerekmektedir.

\section{2 Neo-Liberal Küreselleşme: Yoksulluk, Eşitsizlik ve Gelir Dağılımında Bozulma}

1970'li yıllarda petrol krizleriyle birlikte gündeme gelen stagflasyon (durgunluk içinde enflasyon) sebebiyle, Friedman'ın öncülük ettiği iktisadi liberalizmi savunan Parasalcı (Monetarist) iktisat anlayış tarafından talep artırıcı Keynezyen politikalar yaşanmakta olan krizin nedeni olarak yorumlanmıştır. Sorunlu olmasına rağmen ${ }^{4}$ bu yorum Uluslararası Para Fonu (IMF) ve Dünya Bankası (DB) gibi uluslararası kuruluşlar tarafından benimsenmiştir. Monetarist iktisat tarafından beslenen neo-liberal iktisat anlayışını benimseyen bu kuruluşlar finansal destek için

\footnotetext{
${ }^{4}$ Necef'in (2009: 79) dikkat çektiği gibi bu yorum, aynı dönemde Keynezyen iktisat anlayışının düzenleme tarzının uygulandığı Japon ekonomisinin küresel ekonomide karşı karşıya kalınan talep daralmasına rağmen, neden dünya ticaretindeki payını oldukça istikrarlı bir şekilde artırmaya devam edebildiğini açıklayamamıştır.
} 
kendilerine başvuran ülkelere sağlayacakları desteği sermaye kontrollerini kaldırmaları ve neo-liberal politikalar uygulamaları koşuluna bağlamışlardır. Bu durumla yakından ilişkili olarak 1970'lerden itibaren neo-liberal iktisat anlayışı oldukça hızlı bir şekilde ana akım konumuna yükselmiştir. Bu süreçte sermaye kontrolleri hemen her ülkede kaldırılmış, finans sermaye çok büyük bir akışkanlık ve cezalandırma yeteneği kazanmıştır. Bu durumun önemli bir sonucu olarak hükümetler sermayenin taleplerini, kitlelerin refahına ilişkin sorunları ve reel ekonomiyi göz ardı etme pahasına karşılama eğilimi içinde olmuşlardır.

Finansal küreselleşmeyle birlikte birkaç ülke dışında hemen her ülkenin sermaye kontrollerinden vazgeçmiş olması, para ve maliye politikalarının etkinliğini ciddi ölçüde daraltmaktadır. Diğer taraftan, işsizlik ve enflasyon arasında bir tercih yapılmasının zorunlu olduğu fikrine dayanan Phillips Eğrisi, bilimsel bir kanıta dayanmadığı halde iktisadi düşünceyi adeta esir almıştır. Oysa talep kısıcı politikaların uzun dönemde sürekli ve enflasyonsuz bir büyüme sağlayacağının hiçbir garantisi bulunmamaktadır. Ancak talep kısıcı politikalar çoğu kez yoksulluğu artırmakta ve gelir dağııımını bozmaktadır. Kaboub (2007: 3)'un işaret ettiği üzere bugün ana akım iktisat, yüksek işsizlik dönemlerinde bile hükümetlerin harcamalarını artırmalarına ve emek piyasasına müdahale etmelerine sıcak bakmamakta, yerine ücretleri esnekleştirmeyi önermektedir. Böylece sosyal açıdan çok büyük önem taşıyan tam istihdam bir hedef olmaktan çıkmakta, makroekonomik öncelik enflasyonla mücadeleye verilmektedir. Oysa Stiglitz (2014: 358)'in vurguladığı gibi, toplumsal refahı ve gelir dağııımı adaletini sağlayan en önemli etken hükümetlerin tam istihdam politikalarıdır.

Neo-liberal iktisadi anlayış üretim, istihdam, gelir dağılımı ve kalkınma gibi toplumsal yaşamı ve refahı derinden etkileyen hususlarda kararları piyasa mekanizmasına bırakmayı önermektedir. Ancak özü itibariyle insan haklarına ilişkin bu hususlar siyasal bir nitelik taşımakta ve tümüyle piyasa mekanizmasına bırakılması sosyal adalet açısından olumsuz sonuçlara yol açmaktadır. Teknolojik gelişmenin bir sonucu olarak dünyada büyük üretim ve servet artışları yaşanmakta, ancak geniş kitleler temel özgürlük yoksunluklarından kurtulamamaktadır. Sen (2004: 14)'in altını çizdiği üzere kalkınmanın gerçekleşebilmesi için temel özgürlüklere engel olan eksikliklerin ortadan kaldırılması gerekmektedir. Sen (2004)'ün dikkat çektiği özgürlük yoksunluğu, kamusal olanakların ve sosyal hizmetlerin yetersizliği ile yakından ilişkilidir. Bu yetersizliklerin aşılması ekonomi açısından olmasa da, toplumsal açıdan çok büyük bir önem taşımaktadır. Toplumsal açıdan önemli olan bu hususlar ise, piyasaların keyfine bırakılamaz. Standing (2007: 19)'in ifade ettiği gibi, temel güvence gerçek hak ve özgürlüklerin esasıdır. Temel gelir sayesinde daha çok insan kendi yaşamları üzerinde gerçekten söz sahibi olabilirler.

Weisbrot vd. (2007: 45)'in elde ettikleri sonuçlara göre, 1960-1980 yılları arasında gelişmekte olan ülkelerin büyük bir kısmında kişi başına çıktı \% 83 artış gösterirken, 1980-2005 yılları arasında yalnızca \% 33'lük bir artış söz konusu olabilmiştir. Diğer taraftan artan üretkenlik ile yükselen ücretlerin birbirini beslediği ilişki, 1970'ler itibariyle bozulmaya başlamıştır. Ford (2018: 11)'un belirttiği üzere 1973 - 2013 yılları arasında üretkenlik \%107 oranında artmıştır. Üretkenlikteki bu büyük artışa rağmen, enflasyona göre düzeltilerek hesaplandığında tipik bir üretim işçisinin kazancı 2013 yılına gelindiğinde 1973'teki kazancından \%13 daha azdır.

Neo-liberalizm ile birlikte gelir ve servet eşitsizliği bugüne kadar görülmemiş boyutlara ulaşmıştır. 2017 yılı itibariyle 1,386 milyar nüfusa sahip Çin'in 1993 yılından bu yana sergilediği eşsiz ekonomik performans ve yine bugün 1,339 milyar nüfuslu Hindistan'ın sergilediği yüksek ekonomik performans, düşük ve orta gelirli ülkelere ilişkin istatistiklerde küresel düzeyde 
yoksulluğun dramatik olarak iyileştiği şeklinde bir algıya yol açmaktadır. Ancak bu iki ülke dışarda bırakılacak olursa aslında birçok düşük ve orta gelirli ülkede yoksulluk konusunda fazla bir yol alınamamıştır.

Alvaredo vd. (2019: 343) tarafından hazırlanan Dünya Eşitsizlik Raporu 2018'e göre, dünya düzeyinde 1980 'den bu yana en üst \%0,1 gelir grubunun ekonomik büyümeden aldığı pay neredeyse yetişkin nüfusun alt yarısının aldığı pay kadardır. Küresel düzeyde ise Çin, Avrupa ve ABD'nin temsil ettiği en zengin \%1'in servetten aldığı pay 1980 'de $\% 28$ seviyesinde iken bugün \%33'e yükselmiştir. En yoksul \%75'in payı ise \%10 civarında takılıp kalmıştır. Bu durum, neo-liberalizmin hâkim olduğu son kırk yılda eşitsizliklerin ne kadar artmış olduğunu gözler önüne sermektedir.

\subsection{Koşulsuz Temel Gelir İçin Olgun Dönem: Dördüncü Sanayi Devrimi Süreci}

Temel gelir önerisi, üretimde otomasyonun ve robot kullanımının yaygınlaşmasıyla birlikte işsizliğin artacağı, nitelikli bazı çalışanlar için ortaya çıkacak yeni iş fırsatlarının ise yeterli düzeyde olmayacağı beklentisinin bir sonucu olarak yeniden gündeme gelmiştir.

\subsubsection{Neo-Liberal Küreselleşme Sürecinde Tıkanma}

Büyük Buhrandan sonra yaşanan en şiddetli küresel ekonomik kriz 2008 yılında gerçekleşmiştir. Bu kriz, neo-liberal anlayışın yol açtığı sorunların büyüklüğünü ortaya koyarak bu anlayışın hâkimiyetinde bir kırılmaya yol açmıştır. 2008 küresel krizinin ardından neo-liberalizm uluslararası kuruluşlarda bile etkisini belirgin ölçüde kaybetmiş ve ana akımın dışında kalan heteredoks görüşler kendilerine yer bulabilmeye başlamıştır. Sonuçta kırk yıldan uzun bir aranın ardından sosyal yarar sağlamak amacıyla devletin ekonomide çok önemli rolleri olduğu hatırlanmıştır.

\subsubsection{Otomasyon ve Robot Kullanımının Yapısal Işsizlik Üzerindeki Etkisi}

Ücretli çalışma bugün bütün dünyada hane halkının büyük çoğunluğu için ana gelir kaynağıdır. Ayrıca istihdam, eşitlik, demokrasi, sosyal uyum ve bütünleşmenin gerçekleştirilebilmesi ve sürdürülebilmesine de hizmet etmektedir. Ücretli işler maddi refah, ekonomik güvenlik, fırsat eşitliği ve insani gelişme için kilit önem taşımaktadır. Bununla birlikte, dünya geneline bakıldığında istihdam olanakları sınırlıdır (ILO, 2019: 6).

Teknolojik gelişmelerin ve otomasyonun bir yandan işsizliği arttıracağı, diğer yandan yeni iş olanakları ortaya çıkaracağı görüşünü savunan birçok çalışma bulunmaktadır. Bunlardan Bonekamp ve Sure (2015)'ın çalışması, 4.SD'nin standartlaştırılmış düşük beceri gerektiren işlerde önemli ölçüde azalışa, yüksek beceri gerektiren planlama, kontrol ve akıllı teknolojilerle ilişkili işlerde ise, artışa yol açacağını ileri sürmektedir. Diğer taraftan, Weber (2017) dijital çağda istihdamın azalmayacağını ancak büyük değişikliklere uğrayacağını iddia etmektedir.

Kim, Kim ve Lee (2017)'ye göre, büyük veri, makine öğrenmesi ve robotik alanındaki son teknolojik gelişmeler, bireyler için mevcut istihdam fırsatları üzerinde olumsuz bir etkiye sahip olmaya başlamıştır. İşgücünün makinelerle ikame edilmesi nedeniyle özellikle düşük ve orta gelirli işlerde endişe verici bir azalma söz konusudur. Ford (2018: 14-15)'un işaret ettiği üzere, yakın zamana kadar yaygın kanı otomasyonun yalnızca az eğitimli ve düşük vasıflı işçiler için bir tehdit oluşturduğu şeklindedir. Ancak yazılım otomasyonu ve öngörücü algoritmaların kapasiteleri hızla geliştikçe, üniversite mezunu beyaz yakalılar da işlerini kaybetmekten korkmaya başlamışlardır. 
Frey ve Osborne (2017) çalışmalarında 702 meslek dalı için bilgisayarlaşma olasılığını tahmin etmişlerdir. Bu tahminlere dayanarak, gelecekteki bilgisayarlaşmanın Amerika Birleşik Devletleri $(A B D)$ işgücü piyasası üzerindeki beklenen etkilerini, risk altındaki işlerin sayısı ve bir mesleğin bilgisayarlaşması ile ücret ve eğitim kazanımı olasılığı arasındaki ilişkiyi analiz etmişlerdir. Çalışmanın tahminlerine göre ABD'de toplam istihdamın yaklaşık $\% 47$ 'si, yüksek riskli iş kategorisinde yer almaktadır. Bu yüksek riskli işler belki 10 veya 25 yıl gibi kısa sayılabilecek bir süre içinde tamamen otomasyona tabi olabilirler ve bu da istihdamı ciddi oranda düşürebilir.

\section{Temel Gelir ve Benzeri Uygulamalara Yönelik Ülke Deneyimleri}

Temel gelir ve temel gelir benzeri deneyimler farklı ülkelerde farklı dönemlerde uygulama alanı bulmuştur. Bunlar arasında Manitoba temel yıllık gelir, Alaska daimi fon temettüsü, Hindistan koşulsuz temel gelir, Brezilya koşullu nakit transferi, Finlandiya koşulsuz temel gelir deneyleri en temel örnekler olarak sayılabilir.

\subsection{Manitoba Temel Yıllık Gelir Deneyi: Mincome}

1973 yılında Manitoba ve federal hükümeti bir maliyet paylaşımı anlaşması imzalamıştır. Bu anlaşmaya göre, 17 milyon dolarlık bütçenin \% 75'i federaller, geri kalanı eyalet tarafından karşılanmıştır (Lum, 2017, 1 Mart). Mincome, Winnipeg şehrinde ve Manitoba kırsalında bir gelir garantisi deneyi olarak uygulanmıştır. Bu deneye 1973 yılında Dauphin kasabasında doygunluk alanı olarak adlandırılan pilot proje de eklenmiş ve tüm kasaba sakinleri bir ödeme alma hakkı elde etmiştir (Calnitsky ve Latner, 2017: 373).

Winnipeg ve kırsal Manitoba bölgelerinde rasgele olarak yedi düşük gelirli hane halkı grubu ile bir kontrol grubu tespit edilmiştir. Uygulamaya tabi olan aileler, çalışarak kazandıkları her dolar için belirli bir miktar (35, 50 veya 75 sent) azalan aile büyüklüğüne göre gelir garantisi veya minimum nakit gelir garantisi elde etmiştir (Hum ve Simpson, 1993). Beş yıl boyunca, Manitoba'daki en fakir Dauphin sakinlerine hiçbir koşul söz konusu olmaksızın aylık ödeme yapılmıştır. Kuzey Amerika'da türünün ilk örneği olan bu program asgari geliri ima etmek üzere Mincome olarak adlandırılmıştır. O zamanlar uygulanan benzer Amerikan projelerinden önemli farkı yaşlıları ve engellileri dışarda bırakmamasıdır. Beş yıl içinde Mincome, yoksulluk sınırının altına düşmüş 1000 Dauphin ailesinin yaşanabilir bir gelir elde etmesini sağlamıştır (Lum, 2017, 1 Mart).

Mincome programının birisi en baştan açıklıkla ifade edilmiş diğeri de deney sırasında biçimlenmiş iki temel amacı bulunmaktaydı. İlk amaç, negatif gelir vergisi kavramına dayanan alternatif bir sosyal sistemin ekonomik ve sosyal sonuçlarını değerlendirmek ve özellikle de hane halklarının ve bireylerin yıllık garantili gelire verdikleri tepkileri incelemekti. Deney tasarımında açıkça belirtilmeyen ikinci bir amaç ise, böyle bir sistem uygulanmasının idari ve lojistik zorluklarını tespit etmek şeklinde zaman içinde ortaya çıkmıştır (Simpson vd., 2017: 86).

2011 'de, Forget, nüfus sayımı verilerini kullanarak Mincome programından yararlananların sağlığının ne şekilde etkilendiği üzerine bir makale yayınlamıştır. Temel gelir takviyesi alan grupta genel olarak hastaneye yatış oranlarının (kazalar, yaralanmalar ve ruh sağlığı tanıları için) düştüğü tespit edilmiştir (Lum, 2017, 1 Mart). Forget (2011)'in bir diğer tespiti, deney boyunca daha çok annenin ve gencin işlerini bıraktıkları ya da daha az çalıştıkları şeklindedir. Veriler, yeni annelerin çoğu kez bebeklerine bakmak için evde kalmayı tercih ettiklerini, ailelerine destek vermek için çalışmak zorunda kalmayan gençlerin ise, eğitimlerine devam etmeyi tercih ettiklerini ortaya koymuştur. Deneyin uygulandığı süre boyunca lise mezuniyet oranlarının arttığı gözlenmiştir (Longley, 2017). 


\subsection{Alaska Daimi Fon Temettüsü Deneyimi}

Bugüne kadar var olan tek gerçek koşulsuz temel gelir sistemi Alaska'da uygulanmıştır. Alaska'da Daimi Fon Temettüsü (DFT) olarak adlandırılan bir temel gelir sistemi bulunmaktadır. DFT 1970'lerde Alaska'da keşfedilen petrol rezervlerinden elde edilen yeni ve ciddi bir gelirin sonucu olarak ortaya çıkmıştır.

DFT'nin uygulanmaya başladığı 1982 yılından bu yana, resmi olarak en az altı ay boyunca Alaska'da ikamet eden herkes (şu anda yaklaşık 650.000 kişi) yaşına ve ikamet süresinin kaç yıl olduğuna bakılmaksızın her yıl düzenli bir temettü almaktadır. Alaska'nın Temsilciler Meclisi, devletin yıllık DFT'sini 2019 için kişi başı 1.600 dolar olarak belirleyen bir tasarıyı meclisten geçirmiş̧ir (Bott, 2018, 7 Nisan). DFT, hiçbir şekilde bir geçim ücreti ve tüm gereksinimleri karşılamak için yeterli değildir. Bununla birlikte, gerçek bir evrensel nakit transferi programıdır (Matthews, 2018, 13 Şubat).

Alaska'dan gelen ampirik verilere ilişkin gerçekleştirdiği bir kanıt incelemesinde Marinescu (2017: 4) nakit transferlerinin Alaskalıların daha az çalışmasına yol açmadığı sonucuna ulaşmıştır. Pek çok başka araştırma da aynı sonucu doğrulamaktadır. Jones ve Marinescu (2018), DFT ödemelerinin çalışma saatlerini bir ölçüde azalttığına dair kanıtlar bulmuştur. Ancak, bunun söz konusu ödemelerin etkisiyle artan harcamalar nedeniyle işletmelerin daha fazla iş̧̧i alması ile dengelendiği sonucuna ulaşmışlardır.

\subsection{Hindistan'da Uygulanmış Bazı Koşulsuz Temel Gelir Deneyimleri}

Haziran 2011 - Kasım 2012 arasında, Bağımsız Kadın Derneği (SEWA) ve Birleşmiş Milletler Çocuk Fonu (UNICEF), koşulsuz aylık transferlerin değiştirilmiş ve kontrollü bir çalışma yoluyla etkisini incelemek için iki pilot program başlatmıştır. Pilot program üç dikkat çekici özelliğe sahiptir. Birincisi, sağlanan para transferi cinsiyet, etnik köken ya da servet düzeyinden bağımsız olduğu için evrenseldir. İkincisi, bu hibeler daha önce alınmakta olan ödemelerin yerine geçmemiştir. Üçüncüsü, bu iki pilot program dünya çapında uygulanmakta olan sekiz koşulsuz temel gelir pilot çalışmasının en yenileri arasında yer almıştır. Dahası, bu pilot programlar Asya'da gerçekleştirilen ilk ve gelişmekte olan ülkelerdeki ikinci uygulamadır (Khosla, 2018, 14 Şubat).

Ilk pilot çalışma olan Madhya Pradesh Koşulsuz Nakit Transferi, sekiz köyde yaşayan 6.000 kişiye 12 ila 17 ay boyunca finansman sağlamıştır. Koşulsuz nakit transferi (KNT) alan sekiz köye karşı, 12 benzer köyde para transferi yapılmamıştır. Pilot çalışmalar sekiz köyde ilk kez uygulamaya konulduğunda her yetişkin bir yıl boyunca 200 rupi ve her çocuk ayda 100 rupi almıştır. Bu süreden sonra para miktarı her yetişkin için 300 rupiye, her çocuk için ise 150 rupiye yükseltilmiştir. İkinci pilot çalışma, birisi KNT alan diğeri almayan iki kabile köyünde gerçekleştirilmiştir. Yardım alan kabile köyü için ödenen miktarlar her yetişkin için ayda 300 rupi ve her çocuk için 150 rupi olmuştur. Proje sonunda yaşam koşullarında, beslenmede, sağlıkta ve eğitim düzeylerinde önemli iyileşmeler görülmüştür. Sonuçlar, bu transferlerden yararlananların daha fazla tasarruf etmeye ve ellerindeki parayı daha rasyonel kullanmaya başladığını göstermiştir (Chugh, 2018, 30 Ocak).

Doğrudan nakit transferi yapılan yoksul bireylerin daha iyi beslenme, sağlık ve eğitim seçimleri yapabildikleri ve çiftçilerin borç kısır döngüsünü kırmada başarılı olabildikleri görülmüştür. Cariappa ve Srinivas'a (2019) göre başlıca olumlu etkiler şu şekildedir:

- Hijyende iyileşme,

- Pişirme ve aydınlatma enerji kaynaklarına erişimde iyileşme, 
- Hane halkının borçluluğunda azalma ve hane halkı varlıklarının mülkiyetinde artış,

- Gıda yeterliliğinde artış,

- Sağlık hizmetlerine ulaşım ve hastalığa müdahalede iyileşme,

- Kızların okullaşma, beslenme ve kayıt seviyelerinde iyileşme.

\subsection{Brezilya Koşullu Nakit Transferi Deneyimi: Bolsa Familia}

Bolsa Familia (BF), Brezilya hükümeti tarafından türünün en büyüğü olarak uygulanan yenilikçi bir sosyal refah programıdır. Brezilya Cumhurbaşkanı Lula'nın ilk döneminde, hükümetin sıfır açlık girişimini güçlendiren sosyal program olarak Ekim 2003'te yürürlüğe girmiştir. BF, benzer dört KNT programının tek bir programa entegre edilmesidir (CPI, 2016). Program hem kısa hem de uzun vadeli yoksullukla mücadele etmeyi amaçlamaktadır. Kısa vadede programın amacı yoksulluktan kaynaklanan sorunları azaltmak, uzun vadede ise beşeri birikime yatırım yapmak ve nesiller arası yoksulluk oluşumunu durdurmaktır.

Latin Amerika'daki koşullu nakit transferi programlarının çoğunda olduğu gibi, BF yoksul hanelere - ayda kişi başına 120 R\$' dan (68\$) daha az kazananlar - on yedi yaşına kadar çocuklar ve en fazla üç çocuğu olan hamile kadınlara şartlı aylık nakit transfer sağlamıştır. Latin Amerika'daki diğer programların aksine kompozisyona bakılmaksızın, kişi başına $60 \mathrm{R} \$$ 'dan (34\$) daha az kazanan son derece fakir hanelere de aylık transfer sağlamaktadır. Aşırı fakir çocuksuz haneler için nakit transferine bağlı hiçbir koşul uygulanmamaktadır (Soares, Ribas ve Osório, 2010: 173-174). Program dâhilinde verilen para vatandaşlık kartları ile yapılmaktadır. $\mathrm{Bu}$ kartlar bir banka kartı gibi çalışmakta ve devlete ait bir tasarruf bankası olan Caixa Econômica Federal tarafından verilmektedir. Ülkenin birçok yerinde, hane halkına verilen para yolsuzluğu da azaltıcı bir etki göstermiştir (Lindert vd., 2007).

Beşeri birikime odaklanan BF, standart KNT modellerinden önemli farklılıklar gösteren benzersiz özelliklere sahiptir. Programın en çarpıcı özelliği, bir haneye nakit transferi yapılması için o ailenin aşırı fakir olması, ailede çocuk veya hamile kadın olma şartı aranmaması ve hane halkının kendi gelir beyanlarının esas alınması ve bu beyana göre nakit transferinin yapılmasıdır. Ayrıca bu uygulamanın dikkat çekici bir diğer özelliği başvuru sürecinin âdemi merkeziyetçi bir yapıya sahip olması ve belediyelerin bu sürecin gerektiği gibi yürümesini sağlamada önemli bir rol oynamasıdır (Soares, Ribas ve Osório, 2010: 174).

Bu programların nakit transferi yoluyla kısa vadede yoksulluğun azaltılması ile sağlık ve eğitim harcamaları yoluyla uzun vadeli beşeri birikim sağlanması şeklindeki iki ana hedefi arasında bazı gerilimler bulunmaktadır. Programın koşulsuz bileşeni, diğer benzer programlardaki yararlanıcıların payı ve programın uyum ve izleme için yerel altyapıdan bağımsız bir şekilde genişlemesi gerçeği göz önüne alındığında, BF yoksulluğun ve eşitsizliğin azaltılmasında belirgin yarar sağlamış, 36 milyon insanı aşırı yoksulluktan kurtarmıştır (Pinto, 2018: 145). Ülkenin birçok yerinde, hane halkına verilen para yolsuzluğu da azaltıcı bir etki göstermiştir (Lindert vd., 2007). BF programının maliyet etkinliğini tespit etmek ve hangi bileşenlerin kritik rol oynadığını daha iyi belirleyebilmek için daha fazla araştırmaya ihtiyaç duyulmaktadır.

\subsection{Finlandiya Koşulsuz Temel Gelir Deneyi}

Finlandiya hükümeti, 2017-2018 yılları arasında 25 ila 58 yaş arasındaki 2000 işsize bazı temel sosyal güvenlik ve kazançla ilgili faydaları dışarıda bırakacak kısmi bir temel gelir deneyi uygulamıştır. Bu deney kapsamında yaklaşık 2 bin rastgele seçilen işsize herhangi bir sınırlama 
olmaksızın ayda 560 Euro maaş ödenmiştir. Deneye katılanlar bir işte çalışmaya başlasalar da maaşlarını almaya devam etmişlerdir (De Wispelaere vd., 2018).

ilk resmi sonuç raporuna göre, deneye katılıp ödeme alanlar ödeme almamış bir kontrol grubuna göre ortalama olarak aynı miktarda çalışmışlardır. Bununla birlikte, iki grubun davranış biçimleri arasında bazı farklılıkların olduğu da tespit edilmiştir. Örneğin, deney grubunun temel geliri, işsizlik yardımlarının yerini aldığında; kontrol grubu daha az sosyal yardım ve hastalık izni almaya başlamıştır. Ayrıca resmi rapora göre, test grubunda yer alanlar; kontrol grubunda yer alanlara göre sağlık, stres ve odaklanma kabiliyetiyle ilgili konularda daha az sorun yaşamışlar ve toplumsal meselelere etki etme kabiliyetlerinden daha emin hale gelmişlerdir (Ylikännö ve Kangas, 2019, 14 Nisan).

Simpson vd. (2017: 86) tarafından gerçekleştirilen bir çalışmanın ortaya koyduğu üzere, tüm gelir koruma deneyleri, belirli sayıda katılımcının kısa vadede işgücü arzını azalttığını göstermiştir. Ancak işsizlik uzun vadede beklenildiği gibi artmamıştır. Ayrıca sağlanan temel gelirin başka bazı önemli ve olumlu sonuçları da olmuştur. Örneğin, kısa vadede gelir elde etmek zorunda kalmayanlar, toplumsal intiyaçlara daha iyi karşılık verebilen katma değeri yüksek girişimleri devreye sokabilmiştir.

\section{Türkiye için Koşulsuz Temel Gelir Uygulama Alternatifleri}

Türkiye'nin 2018 yılı Ağustos ayında karşı karşıya kaldığı döviz krizi ekonomik krize dönüşmüş ve ülke bu krizin etkilerinden henüz tam anlamıyla kurtulamamıştır. Hangi nedenle ortaya çıkarsa çıksın karşı karşıya kalınan bir ekonomik krizin en önemli sonuçlarından birisi talebin daralmasıdır. Dolayısıyla krizle etkili bir şekilde mücadele edebilmek için öncelikle talebin artırılması gerekir. Koşulsuz temel gelir, öncelikle tüketim eğilimi çok yüksek olan geniş bir kesime alım gücü sağladığı için güçlü bir kriz karşıtı özelliğe sahiptir. Bu durum göz önüne alınarak Türkiye'nin KTG uygulamaktan sağlayacağı yararın yüksek olacağı söylenebilir.

Bir ekonomide harcamaların hızla kısılması, birçok işletmenin mal ya da hizmetlerine yönelik talebin yetersiz düzeyde kalacağı anlamına gelmektedir. Bu durum, temel amacı kâr elde etmek olan ticari işletmeleri en azından iki ciddi sorunla karşı karşıya bırakmaktadır. Bu sorunlardan birisi, talep daraldığında işletmelerin istihdam düzeylerini koruyarak kârlı çalışabilme olanaklarının azalmasıdır. İşletmeler açısından belki de daha büyük sorun, taksitli satışlarda tahsilâtın yapılamamaya başlanmasıdır.

Piyasaya sunmakta oldukları mal ve hizmetlere yönelik talebin belli bir düzeyin altına inmesi ve tahsilâtta sorunlar yaşamaya başlamaları, işletmeler için işçi çıkarmayı önemli bir gündem maddesi haline getirmektedir. Kriz anında işçi çıkarmak, işletme kârlılığını olumlu yönde etkileyecek rasyonel bir karar olabilir. Talepteki yeni daralmalar yeni işten çıkarmalara, yeni işten çıkarmalar ise yeni talep daralmalarına, dolayısıyla da giderek derinleşen olumsuz bir döngüye yol açmaktadır. Ekonomik kriz dönemlerinde yoğun bir şekilde yaşanan işten çıkarmaların yol açtığı kısır döngünün kırılmasının yolu Keynesyen açık bütçe politikası yoluyla devletin ekonomideki talep açığını kapatmasıdır. Türkiye'de mevcut ekonomik kriz ortamında koşulsuz temel gelir uygulanmaya başlanması, talebi artırıcı güçlü bir etkiye sahip olacağından ekonomiyi tekrar canlandırabilir ve krizden çıkılmasına hizmet edebilir. Tablo 1'de 2006-2019 dönemine ilişkin Türkiye'nin makroekonomik görünümüne ilişkin bazı veriler yer almaktadır. 
Eskişehir Osmangazi Üniversitesi ïBF Dergisi

Tablo 1: Türkiye'nin Makroekonomik Görünümü (2006-2019)

\begin{tabular}{|c|c|c|c|c|c|c|}
\hline Yıllar & GSYH* & $\begin{array}{c}\text { Tüketici Fiyat } \\
\text { Endeksi** }\end{array}$ & $\begin{array}{c}\text { İşgücüne katılma } \\
\text { oranı (\%) }\end{array}$ & $\begin{array}{c}\text { İşsizlik } \\
\text { oranı (\%) }\end{array}$ & $\begin{array}{l}\text { İstihdam } \\
\text { oranı (\%) } \\
\end{array}$ & $\begin{array}{c}\text { Gini Katsa- } \\
\text { yısı } \\
\end{array}$ \\
\hline 2006 & $989.932 .591,96$ & 128,76 & 44,48 & 9,07 & 40,46 & 0,428 \\
\hline 2007 & 1.039.730.731,16 & 140,03 & 44,42 & 9,16 & 40,35 & 0,406 \\
\hline 2008 & $1.048 .519 .070,28$ & 154,66 & 44,90 & 10,03 & 40,42 & 0,405 \\
\hline 2009 & $999.191 .848,06$ & 164,32 & 45,77 & 13,04 & 39,80 & 0,415 \\
\hline 2010 & $1.083 .996 .978,58$ & 178,40 & 46,53 & 11,15 & 41,34 & 0,402 \\
\hline 2011 & $1.204 .466 .934,80$ & 189,95 & 47,39 & 9,16 & 43,06 & 0,404 \\
\hline 2012 & $1.262 .160 .181,69$ & 206,84 & 47,60 & 8,43 & 43,58 & 0,402 \\
\hline 2013 & $1.369 .334 .106,56$ & 222,33 & 48,37 & 9,05 & 43,98 & 0,400 \\
\hline 2014 & $1.440 .083 .364,75$ & 242,02 & 50,48 & 9,96 & 45,47 & 0,391 \\
\hline 2015 & $1.527 .725 .205,51$ & 260,59 & 51,31 & 10,30 & 46,01 & 0,397 \\
\hline 2016 & $1.576 .365 .402,55$ & 280,85 & 51,99 & 10,91 & 46,32 & 0,404 \\
\hline 2017 & $1.694 .133 .563,42$ & 312,14 & 52,83 & 10,93 & 47,07 & 0,405 \\
\hline 2018 & $1.742 .022 .926,44$ & 363,12 & 53.21 & 10,95 & 47,37 & 0,408 \\
\hline 2019 & $1.757 .308 .018,25$ & 418,24 & 52,93 & 13,70 & 45,68 & - \\
\hline $\begin{array}{l}\text { Kaynak: } \\
\text { http://u }\end{array}$ & $\begin{array}{l}\text { Türkiye Cumhuri } \\
\text { vw.tuik.gov.tr/UstM }\end{array}$ & $\begin{array}{l}\text { Merkez Ban } \\
\text { do?metod=te }\end{array}$ & \multicolumn{2}{|c|}{ https://evds2.tcmb.gov.tr/ } & Türkiye İ & tik Kurumu, \\
\hline
\end{tabular}

Tablo 1'e göre 2006-2019 döneminde GSYH \%4,59 artış göstermiştir. Aynı dönemde tüketici fiyat endeksinde \%9,53, işgücüne katılım oranında \%1,35 işsizlik oranında \%4,03 ve istihdam oranında \%0,96 artış gerçekleşmiştir. Aynı dönemde Gini katsayısında ise \%3,7 azalma söz konusudur. Son 50-60 yılda gelişmiş ülkeler arasına katılmayı başarabilmiş az sayıdaki ülkenin gelişmiş ülke statüsüne yükselebilmek için yaklaşık 30 yıl boyunca ortalama yılda \%6-7 büyüdükleri bilinmektedir. Bu durum göz önüne alındığında Türkiye'deki GSYH artışının gelişmiş ülke statüsüne erişebilmek için yeterli olmaktan uzak olduğu söylenebilir.

GSYH yeni hesaplama yönteminde küresel kriz sebebiyle ekonomik daralmanın yaşandığı 2009 baz yılı olarak seçilmiştir. Bu şekilde bazın küçük tutulması, sonraki yıllara ilişkin verilerin daha yüksek olduğu izlenimine yol açmaktadır (Eğilmez, 2016: 1). Yanıltıcı değerlendirmeye yol açabilen bu durum göz önüne alındığında bile işgücüne katılım oranının 2006-2019 öneminde ortalama \%1,35 artması olumlu olarak değerlendirilebilir. Tüketici fiyat endeksinde yüksek düzeyde artışı, ülkede enflasyonun kontrol altında tutulamadığı anlamına gelmektedir. Aynı dönemde işsizlik oranında \%4,03 artış olması ülkedeki büyümenin istihdam yaratmadığını, ekonomide yapısal sorunlar olduğunu göstermektedir. Bu durum işsizlik oranının 2019 yılında \%13,7 seviyesine çıkmış olmasıyla birlikte değerlendirildiğinde Türkiye'nin çok ciddi makroekonomik sorunlarla karşı karşıya olduğu anlaşılmaktadır. Aynı dönemde Gini katsayısında ${ }^{5}$ ufak bir iyileşme söz konusu olsa da eşitsizlik yüksek düzeyini korumaya devam etmektedir. Bu durum Tablo 2' de görülebilir.

\footnotetext{
${ }^{5}$ Gini katsayısı bir ülkedeki gelir dağılımı adaletsizliğini ölçmek için kullanılan bir katsayıdır. Bu katsayı sıfıra yaklaştıkça gelir dağılımı adaletsizliği azalmakta, 1'e yaklaştıkça gelir dağılımı adaletsizliği artmaktadır.
} 
Tablo 2: Eşdeğer Hanehalkı Kullanılabilir Fert Gelirine Göre Gini Katsayısı ve P80/P20 Oranı, 2006-2018

\begin{tabular}{|c|c|c|c|c|}
\hline Yıllar & Gini Katsayısı & P80/P20 Oranı & $\begin{array}{c}\text { İnsani Gelişme Endek- } \\
\text { si: Gelir }\end{array}$ & $\begin{array}{c}\text { İnsani Gelişme Endek- } \\
\text { si: Kişi Başına Gayri } \\
\text { Safi Gelir* }\end{array}$ \\
\hline 2006 & 0,428 & 9,6 & 0,776 & 17.062 \\
\hline 2007 & 0,406 & 8,1 & 0,782 & 17.734 \\
\hline 2008 & 0,405 & 8,1 & 0,782 & 17.662 \\
\hline 2009 & 0,415 & 8,5 & 0,772 & 16.584 \\
\hline 2010 & 0,402 & 7,9 & 0,783 & 17.804 \\
\hline 2011 & 0,404 & 8,0 & 0,796 & 19.481 \\
\hline 2012 & 0,402 & 8,0 & 0,801 & 20.106 \\
\hline 2013 & 0,400 & 7,7 & 0,811 & 21.414 \\
\hline 2014 & 0,391 & 7,4 & 0,816 & 22.146 \\
\hline 2015 & 0,397 & 7,6 & 0,822 & 23.048 \\
\hline 2016 & 0,404 & 7,7 & 0,824 & 23.409 \\
\hline 2017 & 0,405 & 7,5 & 0,832 & 24.702 \\
\hline 2018 & 0,408 & 7,8 & 0,833 & 24.905 \\
\hline
\end{tabular}

Tablo 2'de görüldüğü üzere Türkiye'de Gini katsayısı 2014 yılında 0,391'e kadar düşmüş ancak tekrar yükselerek 2018 yılında 0,408 olarak gerçekleşmiştir. Her ne kadar bu değer dönem başına göre bir iyileşme olduğuna işaret etse da, 0,40'lık bir Gini katsayısı gelir dağılımının oldukça bozuk olduğu anlamına gelmektedir. Ayrıca Tablo 2'de yer alan P80/P20 oranları, Türkiye'de en zengin \% 20'lik dilimde yer alanların en fakir \% 20'lik dilimde yer alanlardan 2018 yılı itibariyle 7,8 kat daha fazla gelir elde ettiğini göstermektedir. Bu değerde özellikle 2007 yılında, daha sonra da 2010 ve 2014 yıllarında önceki yıllara kıyasla önemli sayılabilecek iyileşmeler olmuştur. Ancak diğer yıllarda kısmi geri dönüşlerin olduğu bir yerinde sayma gözlenmiştir.

Dünya genelinde satın alma gücü paritesine (PPP) göre yoksulluk sınırı Dünya Bankası (DB) tarafından saptanarak, ilan edilmektedir. 2005 yılında DB satın alma gücü paritesine göre yoksulluk sınırını günde 1,25\$ olarak belirlemiştir. Yoksulluk sınırı eşik değeri 2011 yılının satın alma gücü paritesine göre yeniden hesaplanmış ve günde $1,90 \$$ olarak tespit edilmiştir ${ }^{6}$ (DB, 2016). Dünya Bankası belirlemiş olduğu günlük yoksulluk sınırını her ülke için ulusal para cinsinden de hesaplamıştır. Türkiye için bu veriler Tablo 3'te yer almaktadır.

\footnotetext{
${ }^{6}$ Yoksulluk sınırı hesaplamasında satın alma gücü paritesi verileri kullanılarak, yerel para birimi ABD dolarına çevrilmektedir. Yerel para birimindeki tüketimin mevcut değeri, ulusal tüketici fiyat endeksi tarafından ilgili satın alma gücü paritesi baz yılına (2005 veya 2011) göre ayarlanmakta ve daha sonra baz yılı satın alma gücü paritesi dönüşüm faktörü olarak elde edilmektedir. Bu kural, PPP faktörlerindeki ( $\triangle P P P=$ PPP 2011 / PPP 2005) yurtiçi tüketici fiyat endekslerindeki ( $\triangle C P I=$ TÜFE 2011 / TÜFE 2005) değişim oranına göre karşılaştırılmasına olanak tanımaktadır.
} 
Eskişehir Osmangazi Üniversitesi ïBF Dergisi

Tablo 3: 2016-2019 Yıllarında Türkiye'de Yoksulluk Sınırı

\begin{tabular}{|c|c|c|c|}
\hline Yoksulluk & Yoksul Sayısı (Bin) & Yoksulluk Oranı (\%) & Dönem \\
\hline Ulusal Yoksulluk Sınırı & $10,842.3$ & 13.5 & 2017 \\
\hline Uluslararası Yoksulluk Sınırı & 184.0 & 0.2 & 2016 \\
\hline Kişi başına günlük 3.3 TL (2016) veya 1.90 \$ (2011 PPP) & & & \\
\hline $\begin{array}{l}\text { Düşük Orta Gelir Sınıfı Yoksulluk Sınırı } \\
\text { Kişi başına günlük 5.5 TL (2016) veya } 3.20 \text { \$ (2011 PPP) }\end{array}$ & $1,442.1$ & 1.8 & 2016 \\
\hline $\begin{array}{l}\text { Üst Orta Gelir Sınıfı Yoksulluk Sınırı } \\
\text { Kişi başına günlük } 9.5 \text { TL (2016) veya } 5.50 \text { \$ (2011 PPP) }\end{array}$ & 7.862 .6 & 9.9 & 2016 \\
\hline
\end{tabular}

Dünya Bankası yaşanmakta olan yüksek belirsizlik nedeniyle 2019 yılında Türkiye ekonomisinde \%1'lik bir büyüme öngörmektedir (Dünya Bankası, Nisan 2019: 1). Ancak belirtmek gerekir ki, bu öngörü mevcut koşullarda fazla iyimserdir. 2019 yılının ilk yarısı yerel seçimlere kitlenmiş ve bu ortamda yapısal sorunlarla gerektiği gibi ilgilenilememiştir. Bu da mevcut sorunların daha da derinleşmesine yol açmıştır. Bu durumun doğal sonucu yoksullaşmanın artmasıdır. Dünya Bankasının TL ve \$ cinsinden ilan ettiği günlük, aylık ve yıllık uluslararası yoksulluk sınırı, düşük orta gelirli yoksulluk sınırı ve üst orta gelirli yoksulluk sınırı Tablo 4 'te görülmektedir. Buna göre her bir vatandaşa uluslararası yoksulluk sınırının üzerine çıkmak için üst sınırın ne olacağı bütçe olanaklarına bağlı olmak üzere aylık en az $99 \mathrm{TL}$, düşük orta gelir düzeyinin üzerine çıkmak için aylık en az 165 TL ve üst orta gelir düzeyinin üzerine çıkmak için de 285 TL verilebilir. Bu şekilde yoksulluk sınırı ve düşük orta gelir düzeyi yoksulluk sınırı temel alındığında tüm vatandaşlara verilebilecek temel gelirin hükümete yıllık maliyeti, bir aylık asgari ücretin (2019 yılı için brüt 2.558,40 TL, net 2.020,90 TL) altındadır. Üst orta gelir düzeyi yoksulluk sınırı için tüm bireylere verilebilecek temel gelirin hükümete yıllık maliyeti ise iki aylık asgari ücretin altındadır.

Tablo 4: Günlük, Aylık ve Yılıı Temel Gelir Miktarları (TL ve \$)

\begin{tabular}{|c|c|c|c|c|c|c|}
\hline Temel Gelir Miktarları & $\begin{array}{c}\text { Günlük } \\
\text { (TL) }\end{array}$ & $\begin{array}{c}\text { Günlük } \\
\text { (\$) }\end{array}$ & $\begin{array}{c}\text { Aylık } \\
\text { (TL) }\end{array}$ & $\begin{array}{c}\text { Aylık } \\
\text { (\$) }\end{array}$ & Yıllık (TL) & $\begin{array}{c}\text { Yıllık } \\
(\$)\end{array}$ \\
\hline Uluslararası Yoksulluk Sınırı & 3,3 & 1,9 & 99 & 57 & 1.188 & 684 \\
\hline Düşük Orta Gelir Sınıfı Yoksulluk Sınırı & 5,5 & 3,2 & 165 & 96 & 1.980 & 1.152 \\
\hline Üst Orta Gelir Sınıfı Yoksulluk Sınırı & 9,5 & 5,5 & 285 & 165 & 3.420 & 1.980 \\
\hline
\end{tabular}

Kaynak: Dünya Bankası'ndan (2019) elde edilen verilerle tarafımızca oluşturulmuştur.

Yoksulluk sınırları baz alınarak uygulanabilecek temel gelirin Türkiye'de satın alma gücü paritesine göre kişi başına düşen GSYH ile reel GSYH içindeki yüzde payları Tablo 5'te verilmektedir.

Tablo 5: Temel Gelirin Kişi Başı GSYH ve Reel GSYH İçindeki Payı

\begin{tabular}{llcc}
\hline \multicolumn{1}{c}{ Yıllık \% } & $\mathbf{2 0 1 6}$ & $\mathbf{2 0 1 7}$ & $\mathbf{2 0 1 8}$ \\
\hline \hline Uluslararası Yoksulluk Sınırı / Kişi Başı GSYH (\$) & 2.580 & 2.424 & 2.403 \\
Düşük Orta Gelir Yoksulluk Sınırı / Kişi Başı GSYH (\$) & 4.345 & 4.083 & 4.048 \\
Üst Orta Gelir Yoksulluk Sınırı / Kişi Başı GSYH (\$) & 7.468 & 7.019 & 6.958 \\
\hline \hline Uluslararası Yoksulluk Sınırı / GSYH (\$) & 0.032 & 0.030 & 0.029 \\
Düşük Orta Gelir Yoksulluk Sınırı / GSYH (\$) & 0.054 & 0.050 & 0.049 \\
Üst Orta Gelir Yoksulluk Sınırı / GSYH (\$) & 0.094 & 0.087 & 0.085 \\
\hline
\end{tabular}

Kaynak: Tarafımızca hesaplanmıştır. 
Tablo 5'de görüldüğü üzere temel gelir uluslararası yoksulluk sınırına göre verilirse GSYH'nin yaklaşık binde 30'una, düşük orta gelir sınıfı yoksulluk sınırına göre verilirse GSYH'nin yaklaşık binde 50'sine, üst orta gelir sınıfı yoksulluk sınırına göre verilirse GSYH'nin yaklaşık binde $88^{\prime}$ ine tekabül etmektedir.

\subsection{Türkiye için Koşulsuz Temel Gelir Uygulama Senaryoları}

Türkiye'de uygulanabilecek koşulsuz temel gelir, uluslararası yoksulluk sınırı için aylık 99 TL, düşük orta gelir sınıfı yoksulluk sınırı için aylık 165 TL ve yüksek gelir sınıfı yoksulluk sınırı için aylık 285 TL'dir. Hükümet, ilk etapta koşulsuz temel gelir uygulamasını Finlandiya örneğinde olduğu gibi öncelikle işsiz bireylere uygulayabilir. Böylece koşulsuz temel gelir uygulama sonuçlarını daha kolay takip edebilir, analiz edebilir ve olası başarısızlık durumunda iyileştirme politikaları belirleyebilir. Daha sonra uygulamayı tüm vatandaşlara sağlayabilecek şekilde genişletebilir. Türkiye'de işsiz bireylerden oluşan koşulsuz temel gelir örnekleminde ortaya çıkabilecek olası maliyetler Senaryo 1'de gösterilmektedir.

Senaryo 1: Türkiye'de İssiz Bireylere Koşulsuz Temel Gelir Uygulaması ve Olası Maliyeti

\begin{tabular}{|c|c|c|c|c|c|}
\hline \multicolumn{6}{|c|}{ Tahmini İşsizlerin (Bin) Tamamı Koşulsuz Temel Gelire Başvurursa } \\
\hline & $\begin{array}{l}\text { İşsiz } \\
\text { Sayısı }\end{array}$ & $\begin{array}{c}\text { İşsiz } \\
\text { Sayısı } \\
(\% 100)\end{array}$ & $\begin{array}{c}\text { Uluslararası Yoksulluk } \\
\text { Sınırı (TL) }\end{array}$ & $\begin{array}{l}\text { Düşük Orta Gelir Sınıfı } \\
\text { Yoksulluk Sınırı (TL) }\end{array}$ & $\begin{array}{c}\text { Üst Orta Gelir Sınıfı Yoksul- } \\
\text { luk Sınırı (TL) }\end{array}$ \\
\hline 2016 & 3.330 & 3.330 & 329.670 & 549.450 & 949.050 \\
\hline 2017 & 3.454 & 3.451 & 341.946 & 569.910 & 984.390 \\
\hline 2018 & 3.537 & 3.537 & 350.163 & 583.605 & 1.008 .045 \\
\hline 2019 & 4.455 & 4.455 & 441.045 & 735.075 & 1.269 .675 \\
\hline \multicolumn{6}{|c|}{ Tahmini İşsizlerin (Bin) \%80’i Koşulsuz Temel Gelire Başvurursa } \\
\hline & $\begin{array}{l}\text { İşsiz } \\
\text { Sayısı }\end{array}$ & $\begin{array}{c}\text { İşsiz } \\
\text { Sayısı } \\
(\% 80) \\
\end{array}$ & $\begin{array}{c}\text { Uluslararası Yoksulluk } \\
\text { Sınırı (TL) }\end{array}$ & $\begin{array}{l}\text { Düşük Orta Gelir Sınıfı } \\
\text { Yoksulluk Sınırı (TL) }\end{array}$ & $\begin{array}{c}\text { Üst Orta Gelir Sınıfı Yoksul- } \\
\text { luk Sınırı (TL) }\end{array}$ \\
\hline 2016 & 3.330 & 2.664 & 263.736 & 439.560 & 759.240 \\
\hline 2017 & 3.454 & 2.763 & 273.537 & 455.895 & 787.455 \\
\hline 2018 & 3.537 & 2.829 & 280.071 & 466.785 & 806.265 \\
\hline 2019 & 4.455 & 3.564 & 352.836 & 588.060 & 1.015 .740 \\
\hline \multicolumn{6}{|c|}{ Tahmini İşsizlerin (Bin) \%50’si Koşulsuz Temel Gelire Başvurursa } \\
\hline & $\begin{array}{l}\text { İşsiz } \\
\text { Sayısı }\end{array}$ & $\begin{array}{c}\text { İşsiz } \\
\text { Sayısı } \\
(\% 50) \\
\end{array}$ & $\begin{array}{c}\text { Uluslararası Yoksulluk } \\
\text { Sınırı (TL) }\end{array}$ & $\begin{array}{l}\text { Düşük Orta Gelir Sınıfı } \\
\text { Yoksulluk Sınırı (TL) }\end{array}$ & $\begin{array}{c}\text { Üst Orta Gelir Sınıfı Yoksul- } \\
\text { luk Sınırı (TL) }\end{array}$ \\
\hline 2016 & 3.330 & 1.665 & 164.835 & 274.725 & 474.525 \\
\hline 2017 & 3.454 & 1.725 & 170.775 & 284.625 & 491.625 \\
\hline 2018 & 3.537 & 1.768 & 175.032 & 291.720 & 503.880 \\
\hline 2019 & 4.455 & 2.227 & 200.473 & 367.455 & 634.695 \\
\hline
\end{tabular}

Kaynak: Dünya Bankası (2019)'dan ve TÜiK'ten elde edilen verilerle tarafımızca oluşturulmuştur.

Senaryo 1'e göre 2019 yılında 4.455 işsiz bulunmaktadır. İşsizlerin tamamının uluslararası yoksulluk sınırına göre temel gelir alması planlanırsa $441.045 \mathrm{TL}$, düşük orta gelir sınıfı yoksulluk sınırına göre temel gelir alması planlanırsa 735.075 TL ve üst orta gelir sınıfı yoksulluk sınırına göre temel gelir alması planlanırsa 1.269.675 TL maliyeti olacaktır. ikinci bir durum olarak işsiz bireylerin \%80'i uluslararası yoksulluk sınırına göre temel gelire tabi tutulursa $352.836 \mathrm{TL}$, düşük orta gelir sınıfı yoksulluk sınırına göre temel gelire tabi tutulursa $588.060 \mathrm{TL}$ ve üst orta gelir sınıfı yoksulluk sınırına göre temel gelire tabi tutulursa 1.015.740 TL maliyeti olacaktır. Eğer işsizlerin yarısı uluslararası yoksulluk sınırına göre temel gelire başvurursa 200.473 TL, düşük orta gelir sınıfı yoksulluk sınırına göre temel gelire başvurursa 367.455 TL ve 
üst orta gelir sınıfı yoksulluk sınırına göre temel gelire başvurursa 634.695 TL maliyeti olacaktır.

KTG, bir toplumda hiçbir bireyin yoksulluk sınırının altına düşmemesini garanti altına alacak bir güvenlik ağı sunmak anlamına gelmektedir. Böyle bir uygulamaya karşı olanlar, KTG'nin bir karşıığının olmadığı argümanını öne sürmektedir. Bu argüman ilk bakışta göründüğü kadar sağlam bir temele oturmamaktadır. Çünkü en azından, temel gereksinimlerini bile karşılayamayan vatandaşların olduğu bir toplumda diğer vatandaşların iç huzuru içinde sahip olduklarının keyfini çıkartabilmeleri pek mümkün değildir. Bu çalışma KTG'nin çok değerli bir karşılığının olabileceğine dikkat çekmektedir. İnsanlık tarihi incelendiğinde toplumların gelişebilmesinin yeni bilgi üretme ve beceri geliştirmeye bağlı olduğu görülmektedir. Gelir dağılımını iyileştirici etkisi sayesinde KTG, toplumda bilgi ve beceri edinme potansiyelinin daha iyi değerlendirilebilmesine olanak tanımaktadır. Bu durum ise, topluma taşan olumlu dışsalıkların, dolayısıyla da sosyal refahın artması anlamına gelmektedir. Böyle bir karşılığın büyük ölçüde garanti altına alınabilmesi için bu çalışmada KTG'nin bir kupon sistemi ile desteklenmesi önerilmektedir.

$\mathrm{Bu}$ çalışma çerçevesinde getirilen kupon önerisi, KTG alanların topluma olumlu dışsallık yayma olasılıklarını zorlayıcı olmadan artıracak şekilde davranışlarını yönlendirmeyi amaçlamaktadır. Bu amaç doğrultusunda sağlanan temel gelirin yaklaşık \%30'unun yalnızca olumlu dışsallık yayma potansiyeli yüksek bilgi, beceri ve kültürel birikimi artırmaya yönelik faaliyetler ile spor faaliyetlerinde kullanılabilecek kuponlar şeklinde verilmesi önerilmektedir. Kupon uygulamasında örneğin beş yıllık bir kullanım süresi tanımlanabilir ve kullanılmaması durumunda kuponlar geçerliliklerini yitirebilir. Böyle bir uygulamanın sonucunda bireyler, harcamalarının çok daha yüksek bir oranını topluma olumlu dışsalık yayma potansiyeli yüksek olan faaliyetler için kullanabilir.

Söz konusu kuponların boşa giderilmeyip olumlu dışsallık yayma potansiyeli yüksek faaliyetlerde kullanılması olasılığını artırmak için devlet, bu kuponların bir yıl içinde kullanılması durumunda üzerinde yazan itibari değerin \%25 kadar daha fazla bir tutarını karşılamayı da garanti edebilir. Örneğin kuponun üzerinde beş yıl içinde kullanılması durumunda 100TL, bir yıl içinde kullanılması durumunda $125 \mathrm{TL}$ yazabilir. Kuponu kabul eden kurum ve kuruluşlar ile devlet en başında kendilerine sağlayacağı ek müşterilerin bir karşılığı olarak ödeyeceği tutar için bir indirim anlaşması yapabilir. Bu anlaşma bir yıl içinde kullanılan kupon için ilgili kurum ya da kuruluşa 125TL yerine örneğin 105TL, beş yıl içinde kullanılan kupon için de 90TL ödeme şeklinde olabilir.

\section{Sonuç Yerine}

Otomasyon ve robot kullanımının artması ve yapay zekâda gerçekleşen hızlı gelişmeler nedeniyle istihdamda önemli kayıplarla karşılaşılması kaçınılmaz görünmektedir. Kaldı ki, çalışan yoksulların sayısında da hatırı sayılır bir artış söz konusudur. Bu çerçevede hükümetlerin emek piyasasını dengede tutmak ve gelir dağılımını iyileştirmek için KTG uygulamaya başlamaları giderek bir zorunluluk haline gelmiştir. KTG, bir topluma hiçbir bireyinin yoksulluk sınırının altına düşmemesini garanti altına alacak bir güvenlik ağı sunmak anlamına gelmektedir. Teknolojik işsizlik kitlesel ölçekte gerçekleşecek olursa KTG toplumdaki her bireye zorunlu intiyaçlarını karşılayabilme güvencesi sağlayabilir. Bireylerin vatandaşlık hakkı olarak temel asgari koşullarda yaşamlarını sürdürebilecekleri bir geliri ifade eden KTG, hem sosyal adalet hem de bireyin üretim sürecindeki rolüne ilişkin bir paradigma değişimidir. KTG daha iyi iş-yaşam den- 
gesi kurmanın yanı sıra, teknolojik gelişmelerin sonucu olarak ortaya çıkan işsizliğin yol açtığı geçim sorunu ve artan istikrarsızlığa çözüm getirme potansiyeline sahiptir.

KTG'yi savunanların temel argümanları, bu yolla bir taraftan refah sistemleri hedeflerinin daha etkin ve daha düşük idari maliyetlerle gerçekleştirilebileceği, diğer taraftan da açlık ve mutlak yoksulluğun tek bir adımla ortadan kaldırılabileceğidir. Ayrıca KTG herkese istediği işi yapabilmek için belli ölçüde bir fırsat eşitliği sağlamaktadır. Bu da bireylerin iş-yaşam dengelerini daha iyi kurabilmelerine ve bu sayede daha mutlu, daha yaratıcı, daha verimli ve daha girişimci olmalarına olanak tanımaktadır. Bugüne kadar gerçekleştirilmiş deneyler bu öngörüyü destekler niteliktedir. KTG'e karşı olanların temel argümanları, böyle bir uygulamanın kamu kaynakları üzerinde taşınamayacak bir yük oluşturacağı, enflasyona yol açacağı, insanların çalışma motivasyonlarını azaltarak tembelliğe iteceği ve bunun da işgücü arzını azaltacağı, karşılıklılık ilkesine aykırı olacağı, gereksiz harcamaları teşvik edeceği ve ücretleri düşürücü etkide bulunacağı şeklindedir. Oysa çalışmanın ilgili kısımları, KTG'e karşı olanların argümanlarının işgücü arzını sınırlı bir ölçüde azaltma dışında pek bir geçerliliğinin olmadığını ortaya koymaktadır.

Farklı ülke uygulamalarının ilk bulgularına göre, KTG sayesinde yaşam koşullarında, beslenmede, sağlıkta ve eğitim düzeylerinde önemli iyileşmeler söz konusu olmuş, KTG uygulamalarından yararlanan bireyler daha fazla tasarruf etmeye ve ellerindeki parayı topluma katkı sağlayabilecek şekilde harcamaya başlamışlardır. Dikkat çekici bir husus, KTG'nin sağladığı ekstra gelirin özellikle aşırı yoksul durumda olanların yaşamlarını iyileştirici etkide bulunmasıdır. Örneğin, KTG çalışan yoksulların işverenlere karşı pazarlık gücünü artırarak sömürücü istihdam ilişkilerinden kaçınmalarını ve kadınların hane halkı harcamaları üzerinde daha fazla söz sahibi olmalarını sağlamış, alkol kullanımında ise azaltıcı bir etkiye yol açmıştır.

Bu çalışmanın bulgularına göre farklı ülkelerde yaşama geçirilen temel gelir gibi uygulamaların en azından üç ortak noktası bulunmaktadır. Bunlardan birincisi, yoksulluktan kaynaklanan sorunların büyük ölçüde azalması; ikincisi, beşeri birikime yapılan yatırımların artması ve üçüncüsü, toplumsal barışın güçlenmesidir. Deneylerin sonuçları, nakit transferi uygulamalarından yararlananların ellerindeki parayı sadece yaşam standartlarını iyileştirmek için değil, çocuklarının eğitimini finanse etmek için de kullandıklarını göstermektedir. Eğitimin ve bilginin olumlu dışsallığı en yüksek faaliyetlerden birisi olduğu bilinmektedir. KTG sayesinde eğitime daha fazla kaynak ayırılabilir ve bu sayede toplumda mevcut bilgi birikimi ve eğitim düzeyi daha hızlı bir şekilde artırılabilir.

Bu makalede KTG sağlama yoluyla topluma olumlu dışsalık yayılmasını önemli ölçüde artırabilecek bir ince ayar önerilmektedir. Bu ince ayar, sağlanacak KTG'nin örneğin \% 30'unun bilgi, beceri ve kültürel birikimi artırmaya yönelik faaliyetler ile sağlıklı olmaya hizmet edecek spor faaliyetleri için kullanılabilecek kupon şeklinde verilmesidir. Böyle bir uygulamanın bir sonucu olarak vatandaşlar harcamalarının normalde olduğundan çok daha yüksek bir oranını bilgi ve becerilerini artırma ve daha sağıklı olmak için harcayabileceklerdir. Bu sayede toplumda bilgi ve beceri daha hızlı bir şekilde birikebilir ve yaygınlaşabilir. Başka bir ifadeyle KTG sayesinde bireyler, öyle amaçlamasalar bile topluma daha önce yaydıklarından daha fazla olumlu dışsallık yayabilir. Böyle bir uygulama, KTG'nin karşılıksız verildiği şeklindeki itirazları da temelsiz kılar.

Dünya Bankası (2019) tarafından satın alma gücü paritesi çerçevesinde yapılan hesaplamaya göre, günlük 1,9 doların altında gelir elde edenler açlık sınırının altında, günlük 3,1 doların altında gelire sahip olanlar ise yoksulluk sınırının altında yaşamaktadır. Bu makalenin yazıldığı 
tarih itibariyle Dünya Bankası (2019) tarafından belirlenen tutarlar her bir vatandaşın uluslararası yoksulluk sınırının üzerine çıkabilmesi için en az 99TL, düşük orta gelir düzeyinin üzerine çıkılabilmesi için aylık en az 165TL ve üst orta gelir düzeyinin üzerine çıkılabilmesi için 285TL düzeyindedir. Bu tutarların üzerine çıkıldığı ölçüde toplumun geniş bir kesimi için yaşam kalitesinin artacağı ve gelir dağılımının iyileşeceği açıktır.

KTG üst orta gelir sınıfı yoksulluk sınırına göre verilirse bile yalnızca GSYH'nın binde 88'ine tekabül etmektedir. Dolayısıyla, KTG uygulaması sanıldığının aksine, bütçe için büyük bir maliyet getirmemektedir. Ayrıca KTG uygulaması, işsizlik nedeniyle hükümetler üzerinde oluşan baskıyı hafifletici bir etkiye sahiptir. Gelir dağılımını iyileştirici ve toplumsal barışı güçlendirici etkileri bir yana, KTG sayesinde bireylerin yüksek bir olasılıkla kendilerine ödenenden çok daha fazlasını olumlu dışsallık olarak topluma geri yansıtmaları da rasyonel bir beklentidir. Özellikle, bir toplumun karşı karşıya kaldığı hırsızlık, vandalizm, şiddet gibi olumsuz dışsallıklar o toplumdaki eşitsizlikler ve dışlanmışıklar ile yakından ilişkili olabilmektedir. Dolayısıyla, KTG uygulamamanın bir alternatif maliyetinin olduğu da dikkate alınmalıdır.

Henüz temel gelir uygulamaları ve yapılan deneylere ilişkin veriler, kesin yargılara varmak için yeterli düzeyde değildir. Dolayısıyla, amacına daha iyi hizmet edecek politikaların oluşturulabilmesi için bundan sonraki çalışmaların temel gelir deneyimleyen ülkelerin sosyoekonomik koşullarındaki değişimleri yakından takip ederek temel gelir programlarının maliyet etkinliğini tespit etmelerinde yarar vardır. 


\section{Kaynaklar}

Alvaredo, Facundo; Chancel, Lucas; Piketty, Thomas; Saez, Emmanuel ve Gabriel Zucman (2019), "Dünya Eşitsizlik Raporu 2018", (Çev. Cimitoğlu, Hande Koçak), İstanbul: Türkiye İ̧̧ Bankası.

Aydın, Erhan; Demiral, Gülten (2019), “İşücü Farklılığını Dikkate Alarak Endüstri 4.0’ın Zorlukları ve Yararları: Kavramsal Bir Çerçeve", İşletme Araştırmaları Dergisi, 11(3), 1976-1990.

BIEN (2017), "What Is Basic Income?", Basic Income Earth Network, Erişim Linki: http://basicincome.org/basicincome, Erişim Tarihi: 01.04.2018.

Bonekamp, Linda; Sure, Mattihas (2015), "Consequences of Industry 4.0 on Human Labour and Work Organisation", Journal Of Business And Media Psychology, 6(1), 33-40.

Bott, Claire (2018, 7 Nisan), “Debate Over Alaska's Permanent Fund Dividend”, BIEN News, Erişim Linki: https://basicincome.org/news/2018/04/debate-over-alaskas-permanent-fund-dividend/

Bowman, Dina; Mallett, Shelley; Cooney-o'donoghue, Diarmuid (2017), "Basic Income: Trade-Offs and Bottom Lines", Brotherhood Of St. Laurence, Working For An Australia Free Of Poverty, Reseach Policy Centre, Working Paper, 136.

Buğra, Ayşe; Keyder, Çağlar (2007), “Bir Temel Hak Olarak Vatandaşlık Gelirine Doğru”, İstanbul: illetişim.

Calnitsky, David; Latner, P. Jonathan (2017), "Basic Income in a Small Town: Understanding The Elusive Effects an Work", Social Problems, 1-25.

Cariappa, A. G. Adeeth; Sriniva, Apoorva (2019), “Universal Basic Income for India: The Way Towards Right to Equality-A Review", Indian Journal Of Economics And Development, 15(1), 142-149.

Chugh, Nidhi (2018, January 30), “Can India Implement Universal Basic Income?”, moneycontrol.com, Erişim Linki: https://www.moneycontrol.com/news/business/economy/can-india-implement-universal-basic-income2457035.html

CPI (2016), "Bolsa Familia in Brazil, Centre for Public Impact Case Study", Erişim Linki: https://www.centreforpublicimpact.org/case-study/bolsa-familia-in-brazil/

De Wispelaere, Jurgen; Halmetoja, Antti; Pulkka, Vile-Veikko (2018), “The Rise (and Fall) of The Basic Income Experiment in Finland", Cesifo Forum, ISSN 2190-717X, Ifo Institut - Leibniz-Institut Für Wirtschaftsforschung An Der Universität München, München, 19(3), 15-19.

Dünya Bankası (2019), "Poverty Equity Brief: Europe \& Central Asia: Turkey”, Erişim Linki: http://povertydata.worldbank.org/poverty/country/tur, Erişim Tarihi: 12.03 .2020

Eğilmez, Mahfi (2016), “GSYH Hesaplaması Değişti, Kişi Başına Gelirimiz Arttı”, Erişim Linki: http://www.mahfiegilmez.com/2016/12/gsyh-hesaplamas-degisti-kisi-basna.html, Erişim Tarihi: 11.06.2019

Eğilmez, Mahfi (2017), "Endüstri 4.0", Erişim Linki: http://www.mahfiegilmez.com/2017/05/endustri-40.html, Erişim Tarihi: 12.03.2020

Ford, Martin (2018), "Robotların Yükselişi: Yapay Zekâ Ve İşsiz Bir Gelecek Tehlikesi”, Duran, Cem (Çev.), İstanbul: Kronik.

Forget, L. Evelyn (2011), "The Town with No Poverty: The Health Effects of a Canadian Guaranteed Annual Income Field Experiment", Canadian Public Policy 37(3), 283-305.

Frey, Carl Benedikt; Osborne, A. Michael (2017), "The Future of Employment: How Susceptible are Jobs to Computerisation?", Technological Forecasting \& Social Change, Vol. 114, 254-280.

Hernandez, Diego (2005), "Universal Basic Income as a Preferential Social Dividend a Proposal for The Colombian Case", The Journal Of Socio-Economics, Vol. 34, 27-38.

Hum, Derek; Simpson, Wayne (1993), “Economic Response to A Guaranteed Annual Income: Experience from Canada and The United States", Journal Of Labor Economics. 11(1), 263-296.

ILO (2019), “World Employment and Social Outlook: Trends 2019”, International Labour Office, Geneva.

Jones, Damon; Marinescu, loana (2018), "The Labor Market Impacts of Universal and Permanent Cash Transfers: Evidence from The Alaska Permanent Fund", NBER Working Paper Series, WP 24312, Erişim Linki: http://www.nber.org/papers/w24312.pdf

Kaboub, Fadhel (2007), "Employment Guarantee Programs: A Survey of Theories and Policy Experiences", The Levy Economics Institute Of Bard College, Working Paper No: 498, 1-23, 


\section{Eskişehir Osmangazi Üniversitesi IïB Dergisi}

Khosla, Saksham (2018), "India's Universal Basic Income: Bedeviled by The Details", Carnegie Endowment for International Peace Publications Department, Washington, DC, 1-94,

Kim, Joon Young; Kim, Kyungsoo; Lee, SuKyoung (2017), "The Rise of Technological Unemployment and Its Implications on The Future Macroeconomic Landscape", Futures, Vol. 87, 1-9.

Laurınavıčıus, Algimantas; Laurınavıčıus, Antanas (2016), "The Concept of Basic Income: Global Experience and Implementation Possibilities in Lithuania", Business, Management and Education, 14(1), 50-63.

Lindert, Kathy; Linder, Anja; Hobbs, Jason; Brière, Benedicte de la (2007, May), "The Nuts and Bolts of Brazil's Bolsa Família Program: Implementing Conditional Cash Transfers in A Decentralized Context", Social Protection Discussion Paper 0709, Washington DC: The World Bank.

Longley, Robert (2017), "Mincome: A Guaranteed Income for All Americans: Eliminating Poverty or The Incentive to Work?", about.com news and Issues, Erişim Linki: http://usgovinfo.about.com/od/healthcare/fl/mincome-aguaranteed-Income-for-all-americans.htm

Lucarelli, Stefano; Fumagalli, Andrea (2008), "Basic Income and Productivity in Cognitive Capitalism", Review of Social Economy, Vol. 66, No. 1, 71-92.

Lum, Zi-Ann (2017), “A Canadian City Once Eliminated Poverty and Nearly Everyone Forgot About It," Erişim Linki: www.huffingtonpost.ca/2014/12/23/mincome-in-dauphin-manitoba_n_6335682.html

Marinescu, loana (2017), "No Strings Attached: The Behavioral Effects of U.S. Unconditional Cash Transfer Programs", Roosevelt Institute, May, Erişim Linki: http://rooseveltinstitute.org/wp-content/uploads/2017/05/no-stringsattached-050417-1.pdf

Masih, Niha (2019, 17 Ocak), "Tiny Indian State Proposes World's Biggest Experiment with Guaranteed Income", Washington Post.

Matthews, Dylan (2018, February 13), "The Amazing True Socialist Miracle of The Alaska Permanent Fund", Vox, Erişim Linki: https://www.vox.com/policy-and-politics/2018/2/13/16997188/alaska-basic-income-permanentfund-oil-revenue-study

More, Thomas (2018 [1516]), “Utopia”, İstanbul: Dorlion Yayınevi.

Necef, Daldal Şule (2009), "Bütünsel Bir Sanayileşme Modeli: Makro Reform Ve Mikro Reform iliş̧kisi”. (Der. Sönmez Mustafa; Konukman, Aziz; Necef, Dal Şule), Alternatif Sanayileşme Önerileri, İstanbul: Kalkedon.

Paine, Thomas (1797), "Agrarian Justice”, The Origins of Universal Grants, 3-16.

Parijs, Philippe Van (1992), "Basic Income Capitalism", Ethics, Vol. 102, No. 3, 465-484.

Parijs, Philippe Van (2004), "Basic Income: A Simple and Powerful Idea for the Twenty-First Century", Politics \& Society, Vol 32 (1).

Pinto, Michele de Lavra (2018), “Meanings of Poverty: An Ethnography of Bolsa Familia Beneficiaries in Rio De Janeiro/Brazil". (Ed. Ystanes, Margit; Strønen, Iselin Åsedotter ), The Social Life Of Economic Inequalities İn Contemporary Latin America, Approaches To Social Inequality And Difference, Palgrave Macmillan, Cham, 129-150.

Prochazka, Tyler (2019, 4 Haziran), “Basic Income's Experimental Wave is over: Time for Policies”, Op-Ed, Opinion, Erişim Linki: https://basicincome.org/news/2019/06/basic-incomes-experimental-wave-is-over-time-for-policies/

Schwab, Klaus (2016), “Dördüncü Sanayi Devrimi”, World Economic Forum, Optimist Yayınevi, No: 423, İstanbul.

Sen, Amartya (2004), “Özgürlükle Kalkınma”. (Çev, Alogan, Yavuz), İstanbul: Ayrıntı Yayınları.

Simpson, Wayne; Mason, Greg; Godwin, T. Ryan (2017), "The Manitoba Basic Annual Income Experiment: Lessons Learned 40 Years Later", Canadian Public Policy, 43(1), 85-104.

Soares, Fabio Veras; Ribas, Perez Rafeal; Osório, Guerreiro Rafael (2010), “Evaluating The Impact of Brazil's Bolsa Familia: Cash Transfer Programmes in Comparative Perspective", Latin American Research Review, 45(2), 173190.

Standing, Guy (2007), "Temel Gelir: Küreselleşen Dünyada Yoksullukla Mücadele Yöntemi”, (Der. Buğra, Ayşe; Keyder, Çağlar) Bir Temel Hak Olarak Vatandaşıı Gelirine Doğru, (Çev. Çekem, İsmail), İstanbul: İletişim.

Stiglitz, Joseph Eugene (2014), “Eşitsizliğin Bedeli: Bugünkü Bölünmüş Toplumu Geleceğimizi Nasıl Tehlikeye Atıyor?”, (Çev. İ̧̧ler, Ozan), İstanbul: İletişim.

Tondani, Davide (2009), "Universal Basic Income and Negative Income Tax: Two Different Ways of Thinking Redistribution", The Journal Of Socio-Economics, 38, 246-255.

Türkiye Cumhuriyet Merkez Bankası, Erişim Linki: https://evds2.tcmb.gov.tr/, Erişim Tarihi: 29.03.2018 
Türkiye İstatistik Kurumu, Erişim Linki: http://www.tuik.gov.tr/ustmenu.do?metod=temelist, Erişim Tarihi: 29.03.2018 Weber, Enzo (2017), "Employment And The Welfare State In The Era Of Digitalisation", Cesifo Forum, 4 / 2017, 22 -28. Weisbrot, Mark; Bakerve, Dean; Rosnick, David (2007), "The Scorecard on Development: 25 Years of Diminished Progress", (Ed. Jomo, K.S.; Baudot, Jacques) Flat World, Big Gaps: Economic Liberalization, Globalization, Poverty \& Inequality, 24-47, Orient Longman, Zed Books Ve TWN, London Ve New York.

Ylikännö, Minna; Kangas,, Olli (2019, April 14), "Finnish Basic Income Experiment Reveals Problems of Conditional Benefits", Guest Contributor Op-Ed, Opinion, Erişim Linki: https://basicincome.org/news/2019/04/finnish-basicincome-experiment-reveals-problems-of-conditional-benefits/. 


\section{Extended Summary}

\section{Unconditional Basic Income in the Framework of the Fourth Industrial Revolution: An Assessment for Turkey}

The main research goal of this study is to evaluate the arguments concerning the unconditional basic income (UBI), which is considered as a partial solution to alleviate poverty and reduce income inequalities. The paper will first explore if there is a relationship between income inequality and neoliberalism that is the dominant economic understanding. Second, it will explore if there is a relationship between an increase in unemployment rates in some countries and the deepening of the 4th Industrial Revolution (4th IR). Third, the paper will question if it is possible to implement policies that will not leave anyone hungry and vulnerable in a capitalist economic system. Fouth, it will briefly evaluate some basic income implementation results from Brazil, India, the US, Canada, and Finland to find satisfactory answers to the above questions. Finally, the paper will provide a modest theoretical contribution.

In the past forty years, when neo-liberalism has become the dominant means of understanding the economy, the distribution of income has deteriorated at both global and national levels. Over the same period, the unemployment rate has also increased in some countries, but not as clearly as the deterioration in the distribution of income. This seems to be closely related to the growing number of companies that use automation and robots in production, with the 4th Industrial Revolution (4th IR) that is currently underway. Although some new jobs and new employment opportunities emergence in this way, it appears that such a development causes more unemployment than it creates.

Capitalism linked man's ability to survive to sell his labor. However, particularly from the 16th century onwards, humanist thinkers argue that social security should be associated with being a member of society and not with individual performance. Basic income, which was first brought to the agenda by Thomas Paine in 1797, has now become a must not only because of the structural unemployment caused by automation and robots but also because of the sustainability of the current economic system.

Basic income and basic income-like experiences have found their application in different countries in different periods. In recent years, experiments on basic income have been conducted on four different continents, including in countries with very strong and very poor welfare systems. These experiences include: Manitoba basic annual income, Alaska permanent fund dividend, India unconditional basic income, Brazil conditional cash transfer, Finland's unconditional basic income experiment. Related data were collected for this study to analyze.

According to the preliminary findings of the experiments carried out in different countries, there have been significant improvements in living conditions, nutrition, health, and education levels thanks to UBI implementations. It is observed that those who have benefited from UBI implementations have started saving more and spending their money such a way to contribute to society. The results of the experiments show that an unconditional basic income makes people happier, healthier and freer to carry out the activities that interest them. Also, basic income has been revealed to hardly reduce the will to work, unlike most people predicted.

It seems inevitable to face significant job losses due to the increase in automation and the use of robots and rapid developments in artificial intelligence. At this stage, to improve income distribution and balance the labor market, it becomes increasingly imperative for governments to provide a safety net to ensure that no one falls below the poverty line. In addition to achieving a better work-life balance, the UBI has the potential to solve the livelihood problem and increased instability caused by unemployment resulting from technological developments. In the study, it was revealed that the arguments of those against UBI did not have much validity, except to decrease the labor supply to a limited extent.

This article suggests that a fine-tuned UBI may increase the spreading of positive externalities to society. This fine-tuning is that $30 \%$ of the UBI to be provided is given in the form of a coupon that can be used for activities aimed at increasing, knowledge and skills and sports activities which will serve to be in good health. Thanks to such an application, citizens will be able to spend a much higher proportion of their expenditure to increase their knowledge and skills and to be healthier. In this way, knowledge and skills can accumulate and easily spread to society.

Contrary to popular belief, performing a UBI does not cost a great deal for the budget. Aside from its effects on improving income distribution and strengthening social peace, it is a rational expectation that thanks to the UBI, individuals will reflect more on society as a positive externality than they are paid. Besides, negative externalities such as theft, drug use, vandalism and violence that society faces can be closely related to inequalities and exclusion in that society. Therefore, it should be noted that there is an alternative cost of not implementing UBI. 